Bence Erika

Filozofski fakultet Univerziteta u Novom Sadu

UDK 821.511.141(497.13)

Németh Ferenc

Učiteljski fakultet na mađarskom nastavnom jeziku

Originalan naučni rad

Univerziteta u Novom Sadu

\title{
FARKAS GEIZA A FEJNÉLKÜLI EMBER CÍMÜ REGÉNYÉNEK EURÓPAI KULTURÁLIS KONTEXTUSA ${ }^{1}$
}

\begin{abstract}
A kutatás ${ }^{2}$ kiindulópontja egy mára már jobbára csak az irodalomtörténet-írás által számon tartott regény, Farkas Geiza A fejnélküli ember címü, Szabadkán, 1933-ban megjelent regénye, amely egy - a kutatók feltételezése szerint -, a térségi kisebbségi magyar irodalomtól térbeli és kulturális értelemben is távol eső interkulturális és -textuális vonzatkört mozgósít. Az ír Dullahan (gonosz tündér), a kelet-németországi „kürtös vadász”, a skandináv „fehér lovon ülö fej nélküli lovas" legendájának motívumai ismerhetők fel a regényben; a főhőst üldöző fej nélküli démon alakjában. A nyugat-európai kultúrákban ismert történet azonban nem a hiedelemmondák és a babonák világából kiindulva terjedt el az európai irodalmi és filmkultúrában, hanem Amerikából. A jelenlegi kutatások szerint egy 1820-ban megjelent novelláskötetre - az amerikai Washington Irving The Sketch Book of Geoffrey Crayon, Gent címü novellagyüjteményére, a benne szereplő a The Legend of Sleepy Hollow címü kísértethistóriára vezethető vissza mediális elterjedtsége. Továbbá feltételezhető, hogy Washington Irving, aki hosszabb ideig élt Angliában, egy Karl Musäus nevü német szerző által lejegyzett hiedelemtörténetet transzportált át a The Legend of Sleepy Hollow című novella világába. Amerikában ismert továbbá egy, a függetlenségi háborúban elesett német zsoldoskatonát mint fej nélküli lovast megjelenítő kísértethistória. A kutatás célja feltárni többek között, hogy miként került be a budapesti, bécsi és eleméri (bánáti) családi kötődésekkel és helyszínekkel rendelkező írói pálya alakulásába, s miként tematizálódott irodalommá ez a nyugat-európai legenda.
\end{abstract}

Kulcsszavak: Farkas Geiza, fej nélküli ember, nyugat-európai hiedelemmondák, Washington Irving, kísértethistória, világháborús poszttrauma

Bence Erika, erikazambo@eunet.rs

Németh Ferenc, ferencnemet@yahoo.co.uk

A tanulmány a Szerb Köztársaság Oktatás- és Tudományügyi Minisztériuma 178017. számú, a Kisebbségi nyelvi, irodalmi és kulturális diskurzusok Délkelet- és Közép-Európában (Diskursi manjinskih jezika, književnosti i kultura u jugoistočnoj i srednjoj Evropi) címü projektuma keretében készült.

2 A szerzőknek a témát más szempontokból megközelítő kutatásai, ill. tanulmányai: ld. Bence, 2014; Németh, 2012. Ezeknek eredményei természetszerüleg épülnek be e tanulmányba is. 


\section{BEVEZETŐ}

Szerteágazó és sokrétű volt Farkas Geizának (1874-1942), a bánáti földbirtokosnak, próza- és tanulmányírónak, jogásznak, közgazdásznak és szociológusnak írói és tudósi életpályája, amelyet mindmáig nem ismerünk teljes egészében. Polihisztori érdeklődése, amely nagy olvasottságával párosult, egy rendkívüli életpályát bontakoztatott ki, amelyben szervesen egybefonódott sokrétü irodalmi és társadalomtudósi érdeklődése. Prózájában gyakran felismerhető a társadalomtudós szemlélete, ugyanakkor szociológiai, tömeglélektani tanulmányaiban irodalmi aspektusok fordulnak elő. Munkásságának megértéséhez, müveinek értelmezéséhez elengedhetetlen ennek az írói-tudósi kettősségnek az integrális szemlélete.

Életútja Budapestről indult, ott született 1874-ben, s 1942-ban ott is hunyt el, magányosan, elhagyatottan. Pedig származása, családi háttere révén egészen más életpálya várt rá. Édesanyja, hajniki Bobor Mária $^{3}$, Kiss Ernő aradi vértanú unokája volt, édesapja pedig, nyújtódi és ikafalvi Farkas Geiza királyi táblabíró (Németh, 2000: 56-57). Az anyagi háttér, a több száz holdas eleméri birtok biztosítva volt, annak megfelelően pedig írónk életpályája is rendhagyó módon indult: négyéves korában már megtanult magyarul és németül írni és olvasni, német dajka nevelte, francia majd svájci nevelőnő foglalkozott vele, iskoláit pedig magántanító felügyelete alatt végezte. A nyarat felváltva, hol Eleméren, a családi birtokon töltötte, hol pedig Rohitson (Rogaška Slatina), a fürdőben (Németh, 2000).

Már gyermekkorában, kilenc-tízévesen lelki gondjai adódtak, amelyek később is éreztették hatásukat. Önéletrajzában vallja: „Kitört rajtam azon erős idegbaj, amelynek következményei a legújabb időkig elhatottak" (Németh, 2000: 58) Eléggé szokatlan hobbinak hódolt ez idő tájt. A bélyeggyüjtés mellett megalapozta gyászjelentés-gyüjteményét is, amely igencsak szokatlannak tủnt a zsenge korú fiatalok körében (Németh, 2000: 59).

Egyetemi tanulmányai során jogi diplomát szerzett, egy ideig hivatalnokoskodott, majd birtokán gazdálkodott, de érdeklődése mindinkább a társadalomtudományok, különösképpen a szociológia és társadalom-lélektan felé irányult (Németh, 2012: 27-42). Főként az egyén és társadalom viszonya foglalkoztatta, azt próbálta munkáiban, tanulmányaiban elemezni, értelmezni. Egyéni meglátású társadalom-lélektani vizsgálódásaival úttörő szerepet vállalt a vajdasági magyar tudományos közéletben (Németh, 2012). Valójában csak napjainkban kezdi a tudomány- és müvelődéstörténet újfent értékelni és megbecsülni lélektani szakdolgozatait, az egyén, csoport, tömeg és társadalom témakörében folytatott kutatásainak eredményeit, a „,sokaság”-ról szóló társadalom-lélektani problémafelvetéseit, amelyekkel annak idején kora előtt járt (Németh, 2012). Farkas Geiza nagyszerüsége abban rejlett, hogy az 1920-as, 30-as években két fontos diszcip-

Bence Erika 2014-es Farkas Geizáról szóló tanulmányában (Bence, 2014) tévesen szerepel az író édesanyjáról szóló adat. Bobor Rozália a nagyanyja volt (ld. Németh, 2000: 57). 
lína, a szociológia és a lélektan határmezsgyéjén ténykedett és alkotott fontos értékszempontokat; új érdeklődési körének vonzatkörében, amelyet még az első világháború idején teljesített ki, s amelynek egyik fontos összegezése $A z$ emberi csoportok lélektana (Farkas, 1916) címü tanulmánya volt. Ezt később még két fontos munkája egészítette ki: a Démonok közt (Farkas, 1923), valamint $A$ társadalmi lélektan köréből (Farkas, 1925). Az első világháború kitörésekor, már 1914ben társadalom-lélektani módszerekkel igyekszik megvilágítani a háború kitörésének okait (Farkas, 1914). E tudományos kutatások „,irodalmi lecsapódása”, irodalmi kontextualizálása lett a Kalangya Könyvtár sorozat első köteteként napvilágot látott $A$ fejnélküli ember (Farkas, 1933) címü regénye. Később kisebb dolgozataiban, folyóiratokban megjelentetett tanulmányaiban és publicisztikájában is kiemelten boncolgatta a társadalom-lélektan egyes aspektusait, megnyilvánulási formáit (Németh, 2007: 101-120).

\section{A Fejnélküli legendájának alapjai Farkas Geiza társadalom-lélektani tanulmányaiban}

Minden bizonnyal az első világháború tragikus eseményei hangolták át a szociológust a társadalom-lélektani vizsgálódásokra, melyeknek eredményeit a Huszadik Században és más tekintélyes folyóiratokban tette közzé (Bori, 1971: 41-48). Mint Bori Imre írja, miután az 1920-as években „,hazaemigrált”, attól kezdődően szinte teljes mértékben a lélektani kérdések kötötték le érdeklődését: „Az ember »démonai« kezdik érdekelni, amelyek a háborúba sodort emberekben oly egyértelmúen megmutatták az erejüket” (Bori, 1971: 41). A háború következményeiről, traumáiról szólva, fogalmazza Farkas, Az emberi csoportok lélektanában: „Utat tör magának az a meggyőződés, hogy egy győzelmes háború árán egy más nemzet fölött szerzett előny sok szenvedést jelent ugyan a legyőzöttekre, de majd ugyanannyit a győztesre nézve, melynek csak egyes rétegei, tagjai látják a diadal hasznát" (Farkas, 1916: 158).

Az egyén és a társadalom viszonyát taglalva jut el Farkas - Démonok közt címü tanulmányában - a démonok, illetve a démoniság fogalmához, amely segítségével már értelmezni tudja ezt a viszonyt. Kiindulópontja szükségszerüen a szakirodalom, mindenekelött a német és a francia; Goethe, Wahle, Nietzsche, Spencer, Scopenhauer, Weininger, Barbusse, Mauthner, Leopold, Le Bon, Coppée, Ruskin, Bergson, Tagore és mások vonatkozó értelmezéseit érvényesíti (Farkas, 1923). Farkas Geiza Goethe démonértelmezéséből indul ki, amelyre azután ráépíti saját meglátásait, értelmezéseit. Ennek nyomán Farkas Geiza démoninak nevezi „azt a lényt, amely [...] minden más közé lép, minden mást elválaszt és összeköt” (Farkas, 1923: 2). Alapvető tézise, hogy ,a démoni minden testben és testetlenben megnyilatkozik, sőt állatoknál a legkülönösebb érdekességgel lép elő, mégis az emberrel áll a legcsodálatosabb összefüggésben és egy hatalmat képez, mely, ha nem ellentétes az erkölcsi világrenddel, keresztezi azt" (Farkas, 1923: 3). A továbbiakban a démonokról nem, mint „különfajú lényegekről” beszél, hanem a 
démoniságról, mint sajátságról, amely a legkülönfélébb élőlényeknél, sőt élettelen tárgyaknál is előfordulhat (Farkas, 1923: 3). Démoninak nevez egyes „természeti vagy társadalmi erőket, vagy éppenséggel a minden emberben müködő indulatot, amelyet gyakran démonként személyesítünk meg. [...] A démon olykor változtatja, az ember tetteihez szabja magatartását, még alkudni, egyezkedni is enged magával" (Farkas, 1923: 4-5).

Farkas Geizát - s ezt az általa meghivatkozott szakirodalom is bizonyítja -, zömmel német és francia müvek irányították a démon és démoniság képzete felé, s ugyancsak joggal feltételezhető, hogy később, a Fejnélküli ember (regénybe transzportált) alakja is részben onnan származhatott. Itt kell felhívni a figyelmet Farkas Geiza gazdag, sokfelé tájolódó olvasáskultúrájára, amelynek alapját mindenképpen gazdag, még a 18. században megalapozott családi könyvtára képezte, amelyet ő személyesen is, élete során több ezer kötettel gyarapított ${ }^{4}$.

Hogy pontosan megértsük, mi történik Nagybáti György személyiségével, $A$ fejnélküli ember főhősével, Farkas Geiza társadalom-lélektani tanulmányait, mindenekelőtt $A$ háború lélektana: az idő harcokat újráz és a Démonok közt címü tanulmányainak kitételeit hívhatjuk segítségül. A tudós ugyanis a társadalomban olyan jelenségeket lát, amelyek az idővel törvényszerüen megismétlődnek, illetve jelen vannak. E felfogás értelmében a háború is ilyen jelenség az emberiség történetében, amelynek okai társadalom-lélektani mozzanatokra vezethetők vissza: „,...a háborúk manapság nem kis részben azért lehetségesek, mert már a múltban előfordultak. [...] Ezt a csodát csupán a lezajlott háborúk emlékei, az emberek sok nemzedéken keresztül táplált atavisztikus hagyományai, militarista nevelési módjai teszik lehetővé" (Farkas, 1914).

Démonok közt című nagytanulmányában az emberi pszichét jó és rossz démonokkal folytatott küzdelmek ,,helye”-ként határozza meg, ahol ,[...] a démon sohasem közömbös, ritkán tárgyilagos vagy igazságos; rendszerint szinte vakon áll valakinek a szolgálatában, vagy tör megrontására, a legnagyobb mértékben szubjektív. Az erkölcsi álláspont nem idegen tőle; az embert jó démonja rendesen az erény útjára igyekszik irányítani, rossz démonja pedig bünbe sodorni” (Farkas, 1923: 4). A démon jelenlétének és megnyilatkozásainak különböző szintjeit különbözteti meg a nyelvi szinten jelentkező démoniságtól az elhalt emberekre mint démonokra való emlékezésen át a démon „emberiesítés”-éig (Farkas, 1923: 12).

\section{A FEJNÉLKÜLI EMBER, FARKAS GEIZA REGÉNYE}

A beszédben indukálódó/kifejeződő képzelet, az álom és a látomás képezi azt a hármas kiterjedtségü, egymással összefüggő tartományt, amelyben Farkas Geiza 1933-ban napvilágot látott regénye, A fejnélküli ember démoni alakja megjelenhet

Azok jó része később, halála után (Marton Andor könyvtárával együtt) a nagybecskereki Petőfi Művelődési Egyesület Könyvtárának alapját képezték. 
és alakot ölthet. A korabeli kritika „nagyszabású pszichopatológiai felépítésü regény"-nek (Bisztray-Csuka, 1943: 315) minősíti.

A fejnélküli ember főhőse, Nagybáti György a „démonok között” kibontakozó lét minden jelentését és megnyilatkozását átéli, miközben a különböző, egyre súlyosabb szintekre való átlépés egybeesik lélektani és egzisztenciális (családi és szerelmi élete, társadalmi szerepe) leépülésének folyamatával, ami az önmagában lakó démon elpusztításáig, rejtélyes és furcsa haláláig vezet (Bence, 2014).

Nagybáti György jómódú városi fakereskedő, köztiszteletben álló polgár és tisztességes családapa, éjszakánként azonban egy „fej nélküli” emberrel, azaz egy démonszerü lénnyel küszködik. A közvetlen narrátori szólam nem bontja ki számunkra a történések valósághátterét, de a személyéhez kapcsolódó kétértelmü kommentárokból sejtjük, hogy a vagyona megalapozásához szükséges alaptőkét nem becsületes úton szerezte. ,[...] eszébe juthatott, hogy nem is olyan régen, ő is csak olyan volt, mint mi, még olyan sem, mert ő nem is telepen dolgozott, hanem kinn az erdőben. [...] De hogy is lehet valakinek ekkora szerencséje! - ebben a felkiáltásban szürődött ki valamennyiök legközösebb gondolata" (Farkas, 1933: 26). Az egzisztenciális helyzetükkel elégedetlen munkások (az 1930-as évek elején, a gazdasági válság idején játszódnak az események!) mellett a társadalom más rétegéhez tartozó, Nagybátival kapcsolatotot tartó személyek (pl. asztaltársaságának tagjai) is kommentálják anyagi és társadalmi felemelkedésének történetét: ,[...] csak jó feje van annak, aki tíz év alatt semmiböl egy ilyen nagyszerü fatelepet teremtett" (Farkas, 1933: 15). Többször maga is megjegyzést tesz önnön léthelyzetére és családi állapotára:

„Ott nem is lát olyasmit, ami nem való, legalább szüleinél marad... oda nem jöhet utána ő, ott az ilyen finom úri nőnek... aki mindenen megsértődik, elutálkozik... aminőt nem szabad lett volna elvennem... Hiszen ha most kereskedö vagyok is, azelőtt csak erdei munkás voltam, ő pedig okleveles tanítónő, járásbíró leánya... Nem vagyunk egymáshoz valók, ezt már akkor látnom kellett volna, mikor a barátaim annyira ajánlották nekem ezt a házasságot” (Farkas, 1923: 19).

A különleges anyagi és társadalmi felemelkedés történetét a narrátor is elmeséli:

„Nagybáti Györgyről az egész világ vagy legalább városának egész világa tudta, hogy ritka értelmes, erőteljes, törtető üzletember, aki ugyan alaposan kivette részét az ifjúkor bolondságaiból, botlásaiból is, de azután mégis a legjobb útra tért. Szegény, sőt nagyon szegény emberek gyereke volt, mégis járt iskolába, még valamely váratlanul bőkezűvé lett úri keresztapa jóvoltából polgárit is végzett, majd a gyermekkori kanászkodás emlékeivel gazdagon irodába került. Ott azonban nem vált be, sokszor munka helyett elcsatangolt, leányzókkal szerelmi és legényekkel verekedési ügyekbe keveredett, még a reá bízottakról sem tudott tökéletesen elszámolni - visszaesett gyermekkora legfeketébb szegénységébe. Ebben sem érezte ugyan magát éppen elveszettnek; izmos karjával mint erdőmunkás még többet keresett, mint írnok korában a fejével. Egyszer aztán 
valóságosan és állandóan rámosolygott a szerencse; bár semmit meg nem tagadott magától, mindig volt pénze. Elköltözött vidékröl és egy városban, ahol senki sem ismerte, egy szerény kis tüzelőanyag-boltot nyitott. Ebböl alig három év alatt hatalmas fatelep lett, melynek tulajdonosát mindenki becsülte, barátul kereste, mindenhova bejelölte, beválasztotta. Makfalvy járásbíró hozzáadta a lányát, volt már egy fiúk, aki úgy látszott, a legszebb összhangban örökölte anyja finom idegzetét és apja erős tehetségét" (Farkas, 1923: 65-66).

A halálát követően megindult szóbeszéd pedig már konkrét megjelöléseket is tartalmaz:

- Azt mondják, - ismerte el Várkai tanár, - hogy az összeomláskor mindenfélével üzérkedett, gazdátlan vagy ezekké tett marháktól kezdve lepecsételetlen bankókig és megpecsételt sorsú emberek házaiig. Így lett a szegény erdei munkásból néhány év alatt nagykereskedő.

- Ez valószínü, - mondta Vucsetics Bátó, - de ez még kedvező eset. Beszélnek, hiszen tudjátok, valami Pantelics nevü dolnja tuzlai marhakupecről, mások meg egy Neumayer osztrák bevásárló tisztről, akit a háború idején Bród környékén meggyilkolt és kirabolt volna. Erre vonatkozólag a legutóbbi időben, mikor már nem volt egészen ura a szavainak, többször el is árulta magát...

- Hogyan? mondd csak el még egyszer, - kivánták többen is.

- Hát mindig valakiről beszélt, akit megöltek, a fejét levágták és a folyóba dobták.

Azóta fej nélkül örökösen a gyilkosa körül settenkedik és lesi a pillanatot, mikor bosszút állhat rajta. A gyilkos pedig nem más, mint Nagybáti. Érdekes, hogy a fejetlen emberrel együtt a fiát, a kis Karcsit is emlegetni szokta, azt féltette legjobban attól a halott ellenségtől. - De mintha néha már ettől a fiútól is félt volna" (Farkas, 1923: 229-230).

Farkas Geiza születésének századik évfordulóján az Üzenet folyóiratban tanulmány jelent meg, amelyben $A$ fejélküli embert mint „dzsentri-regény“-t láttatja a szerző (Csetvei, 1974). Kétségkívül van igazságtartalma a „fölülházasodó“ és a jelölt társadalmi réteg tagjait utánzó Nagybáti Györgyről kialakított jellemképnek. Jelenkori kutatásaink ugyanakkor arról győztek meg bennünket, hogy a vajdasági magyar irodalom ezen alkotása sokkalta inkább következik szerzőjük társadalomtudományos érdeklődéséböl és kapcsolódik ilyen tárgyú publikációinak sorozatához, mint a 19. század végi dzsentriregények világához, másrészt a „fej nélküli démon” a nyugat-európai hiedelemmondák és legendák kultuszára épülő amerikai rémromantika hagyományával mutat rokonságot, amelyet nemcsak a 19. század végi és a 20 . század eleji európai irodalmi, hanem a populáris kultúra is kiaknázott (színpadi adaptációk, fej nélküli portrék ${ }^{5}$ etc.).

The Headless Horseman (1922), némafilm Edward Venturini rendezésében, Ichabod Crane szerepében Will Rogers. New Yorkban készült, a Hudson folyó völgyében. 


\section{A FEJ NÉLKÜLI EMBER LEGENDÁJA FARKAS GEIZA REGÉNYÉBEN}

A regény elbeszélői szólama nem tartalmazza a kórisme előzményeinek, illetve konkrét valóságtartalmainak leírását. Ezekre csak a már idézett szóbeszédből, illetve a főhős látomásainak leírásából következtethetünk. Leghatásosabb és - a sok közül - leghosszabb és -pusztítóbb látomásában Nagybáti György katonaszökevényként jelenik meg Boszniában. A hazafelé tartó úton azonban összetalálkozik egy marhakereskedővel, aki felismeri benne a dezertőrt, ezért megpróbálja manipulálni és kihasználni. Ö azonban Brodnál megöli a kupecet, elveszi a nála levő tekintélyes pénzösszeget és vagyontárgyakat, $\mathrm{s}$ hogy ne tudják azonosítani a holttestet, levágja a fejét és bedobja a Szávába. A megjelenített látomás - legalábbis a közlés szempontjából - meglehetősen kihagyásos, szaggatott, töredékes, utalásszerü:

„[....] Ujabb álomváltozás. Nagybáti ismét fiatal, ismét szökött katona, ismét csavargó. Most ő térdel a másiknak mellén. - Már ez nem mozdul, nem is hörög, vége, akár annak az orosznak, akivel Mármarosban a járőrön összeölelkeztem.... A kése már az enyém, mi is van még nála? Egy tárca, jó tömött tárca, pompás száz- és ezerkoronásokkal. Ezeket szépen elveszem, rám fér, mindenesetre inkább, mint ő rá.... Csak persze a tárcából kiszedem; nálam ugyan semmi se legyen a pénzen kívül, ami az övé volt.... Jó lesz a bankóknak a kapcarongyban is, amit a katonai felszerelésböl, az angyalbörömből még el nem adtam.... Már azért is el kellett hallgatnia, hogy ne fecsegje ki valahol, micsoda lógós katonát látott.... mert kitalálta, hogy az vagyok.... Most már tovább mehetek Vukovárra, vagy akárhova. Már könnyebben bújhatok el a katonai nyomozók elöl is, hisz van pénzem... De mi lesz, ha ôt itt megtalálják, megismerik, keresésére indulnak a gyilkosának, felverik az egész vidéket? El kell, hogy tünjék, de hogyan? [...] Elég, ha a fejét nem találják. Az belefér még a batyujába is; a többit itt hagyhatom, legfeljebb, hogy gallyat hordok rá... Éppen jó, hogy kést hozott magával; ezzel levághatom a fejét... Hisz háború van, ki-ki úgy marad életben és boldogul, ahogy tud, csak lehetőleg úgy, hogy nagyon véres ne legyek... No hát rajta, ha most mészáros lennék... Ujjaj! Még egyszer kinyitja a szemét, megmozditja a kezét! Hogy néz rám, hogy néz! Az ajka is mozog, mintha egyszerre könyörögni akarna nekem, vagy megátkozni, belém harapni... Hamar, hamar! Már nyisszen, már reccsen! Kezemben a fej, bele a batyuba; a többi holmi csak maradjon és most lógj, siess, fuss... Csak mégis vigyázz, senki rád figyelmes ne lehessen; inkább lopózkodj az erdei mezsgyéken és menj közömbösen, nyugodtan, mikor tágasabb, világosabb útra érsz ki..." (Farkas, 1933: 178-179). 
A szörnyű és véres - Nagybátit egyszerre kétségbeesett menekülőnek és elvetemült gyilkosnak bemutató - látomás egyik legfontosabb, a háborút elkülönítő létállapotként magyarázó kitétele, miszerint „háború van, ki-ki úgy marad életben és boldogul, ahogy tud" (Farkas, 1933: 179), ami a szökött katona lelkivilágát és gondolkodását megváltozott állapotként fogja fel, s visszautal saját, 1923-ban napvilágot látott Démonok közt című tanulmányára: „,....katonaruhában hivatali helyiségben [...] a legtöbb ember - jó és rossz értelemben - egészen másként viselkedik, cselekszik, mint házi ruhában, családi vagy baráti körben." (Farkas, 1923: 29), illetve meghatározott körülmények között -ilyen lehet a megkülönböztető viselet és a jelvény (katonaruha, rangfokozat), de a szertartások és megszólítási formák is („,katonaszökevény”- B. E. megj.) - „,az ember valóban mássá, kevésbé emberré és inkább démonná" (Farkas, 1923: 29) válik. Csak erről az alapról (a megváltozott lelkiállapot szemszögéből) magyarázható ugyanis, hogy az alapvetően tisztességes Nagybáti ilyen szörnyủ cselekedetre volt képes, majd a háborút követően nemcsak ,visszaáll” eredeti társadalmi státusa, de a korábbihoz képest magasabb életvezetési formát követ és alkot magának.

Nagybáti a gyilkosságot követően „világosabb útra” (Farkas, 1933: 179) szeretne lépni, amit nemcsak térben zajló cselekedetként, hanem lelki értelmü elhatározásként is értelmezhetünk. A marhakereskedő pénzét felhasználva és a háborús konjunktúrát kihasználva megalapozza vagyonát; egyszerủ favágóból fatelep-tulajdonos és kereskedő lesz, aki feleségül veszi a város egyik legelőkelőbb családjának leányát. A fejnélküli ember látomásától, önnön büntudata tárgyiasult képétől, saját démonától azonban sohasem szabadulhat, ami személyiségének szétesését és pusztulását okozza. Ilyen értelemben Farkas Geiza regénye, a később „vietnami szindróma”-ként ismert kórtörténet egyik korai prototípusa, a háborús poszttrauma első regényszerü feldolgozása a (vajdasági) magyar irodalomban.

\section{A démon jelenléte a regény nyelvi/beszédbeli szintjein}

A fejnélküli ember regénykezdő elbeszélői reflexiója a történések irreális tartományaira (itt a felhőkre kivetített képzelet világára) irányítja a figyelmünket: „Van egy világ, nem messze, alig néhány kilométerre, sőt, annyira se tőlünk, vagy inkább fölöttünk melyben mindent megláthatunk, amit idelent csak elképzelni szoktunk. Nem kézzelfogható, de mégis valóságként jelenik meg ott előttünk minden, ami nálunk van és hozzá az is, ami csak lehetne, sőt ami itt lehetetlen" (Farkas, 1933: 9).

A kezdő szituációban a gyermekével együtt a folyóparton heverésző Nagybátit pillantjuk meg, aki kezdetben élvezettel hallgatja a kisfiú képzelgéseit a fölöttük úszó felhőkről. Egyik véletlen megjelenített kép azonban az apa váratlanul arrogáns reakcióját váltja ki: „Ott egy ember szalad, úgy hogy a lábai csaknem egy vonalban vannak, a karjai is, melyekből az egyiket előre, a másikat hátra veti. De feje nincs, vagy talán, ott tovább repül el tőle...” (Farkas, 1933: 11). Elsődleges feltételezésünk, miszerint az „elszalad a fejétöl“ kifejezés frazeológiai egységnek 
tekinthető, nem igazolódott be a vonatkozó szakirodalom ${ }^{6}$ révén, szerepel viszont Jókai Mór A löcsei fehér asszony (1884) címü regényében. Czelder Orbán (16741717) kuruc ezredesről mondja Georg Löffelhoz (1661-1719) tábornok: „Ez az ember előbb-utóbb el fog szaladni a fejétől“ (Jókai, 1974: 359). Megtalálható viszont a ,jó feje van" frazeológiai egység több forrásban ${ }^{7}$ is. Ez a második olyan beszédbeli fordulat, amelynek elhangzását követően Nagybáti ugyancsak elutasítóan reagál. A Szokolovics vendéglőben, a Hazug névre hallgató asztaltársasága körében mondják rá, hogy „,jó fejére“ (Farkas, 1933: 15). De Nagybátit zavarja egyik alkalmazottja, Mehurek félrebillent feje (,csak lóg a nyakán“ [Farkas, 1933: 33.]) éppúgy, miként felzaklatja a Marie Antoinette életéről szóló szomorújáték ${ }^{8}$, amit a fiával együtt néz meg a helyi moziban: „Szörnyüség, szólt a tolongásban melléje került Várkai tanárhoz, az a sok lefejezett ember!” (Farkas, 1933: 33).

Mindezek a mozzanatok azonban csak a főhős lelkiismereti válságára, a büntudat hárításának jelenségére utalnak. A feleségét hütlenséggel vádoló férj magatartása azonban már teljesen irreális mozzanatokat tartalmaz, kóros lelkiállapotot feltételez. Ugyanis nem egy valóságos férfival gyanúsítja meg az asszonyt, hanem az őt üldöző fejnélküli ember démonával. Ezért jelent számára bizonyítékot az a körülmény (a fejpárna sima volta), amit az asszony épp ellenérvként hoz fel a hütlenség vádjával szemben:

„Aztán hirtelen a saját ágya felé fordult és tompa, rekedt hangon azt mondta: itt valaki volt előttem!

Mária szemei tágra nyiltak. Itt valaki? kérdezte. Ugyan mire, kire gondol? Térjen magához, én voltam csak itt és sírtam maga után... úgy néz mintha nem hinne nekem. Még ezt is meg kellett érnem! De hát ha nem hisz a szavamnak, nézzen oda: a párnája egészen sima; ott nem fekhetett senki. [...]

- Könnyü ezt mondani, éppen arról, hogy ott a fejpárna sima, tudom, hogy ki volt itt, engem nem lehet becsapni!" (Farkas, 1933: 17)

A józan logika kikapcsolása, a tények feletti/melletti átsiklás és elbeszélés ugyancsak jellemzi ezt, azaz Nagybáti magatartását, miként az is, hogy a nyelvnek nincs meggyőző ereje számára. Kezdetben Nagybáti még maga is vissza-

A következő forrásokban néztük meg: Forgács Tamás: Magyar szólások és közmondások szótára. Akadémiai Kiadó, Budapest, 2013. O. Nagy Gábor: Magyar szólások és közmondások. Gondolat, Budapest, 1966. Bárdosi Vilmos szerk.: Magyar szólástár, Tinta Könyvkiadó, Budapest, 2003.T. Litovkina Anna: Magyar közmondástár. Tinta Könyvkiadó, Budapest, 2005. O. Nagy Gábor: Mi fán terem? Gondolat, Budapest, 1979. Szemerkényi Ágnes: Szólások és közmondások Osiris, Budapest, 2009. Gerencsér Ferenc szerk.: Magyar közmondások, szólások diákoknak. Puedlo Könyvkiadó, Debrecen, [2008]. Margalits Ede szerk: Magyar közmondások és közmondásszerü szólások. Kiadta Kóki Lajos, Budapest.

7 Pl. Magyar szólások és közmondások adatbázisa. Bárdosi Vilmos szerk. Tinta Könyvkiadó, Budapest, 2012.

Ezek szerint: jó feje van (sz) (neutr)

- a) gyors felfogású;

-b) könnyen tanul \{vkinek\}.

8 Behatóbb vizsgálatok nélkül nem lehet kideríteni, hogy a múlt század húszas éveinek végén vagy harmincas éveinek elején valóban létezett-e ilyen filmprodukció, tehát van-e referenciális alapja ennek a regénybeli epizódnak. Jean Renoir La Marseillaise című ismert filmjét csak 1938-ban mutatták be. 
visszakapcsol a realitások világába, megpróbálja visszavonni korábbi feltételezéseit. „Megkérem az asszonyt, jöjjön vissza, nem hiszek róla semmi rosszat, én is megjavulok. De fog-e nekem hinni. És ha ő megint eljön, amikor én nem vagyok itthon, és akkor - jaj mi lesz!" (Farkas, 1933: 19) - hangzik a felesége hütlenségére vonatkozó vádak józan átgondolása és visszavonása, ugyanakkor a gondolkodás logikus menete rögtön kisiklik, amikor a démon képe kerül előtérbe. Hasonló degeneratív gondolkodás csapdájába esik a fatelepén történt gyújtogatás esetében is, amikor szinte egyértelmü, hogy a telepről korábban elbocsátott elégedetlen munkások bosszújáról van szó. A fia elbeszélését - aki kiment egy kisgyermeket az égő épületből, majd határozottan és világosan állítja, hogy saját akaratából tette ki magát életveszélynek - sem hiszi el: „Mindent elhiszek, amit ez a gyerek mond, de úgy tetszik, nem mondott el mindent. Nem gondolom, hogy magától szaladt el tőlünk az irodából... biztosan hivta valaki, aki veszedelembe kivánta sodorni, aki rosszat akar neki is, nekünk is... És gondolom is, hogy ki” (Farkas, 1933: 137).

\section{A démon mint halott ember}

Az emberi pszichét átható démon Farkas Geiza szerint megjelenhet ,álom-, láz-, és hallucináció-képek, hangok" (Farkas, 1923: 13) formájában. A fejnélküli ember démona legtöbbször ilyen formában, Nagybáti rémálmaiban fordul elö. E zavaros és töredékes rémlátomásokban az eképp kísértő démonnak csak néhány vonását ismerjük meg. A sok közül három domináns jelenetet szeretnénk kiemelni. Az első egy (szerencsés kimenetelü) párbaj következménye, amely Nagybátit érintő becsületbeli ügy, de mert ellenfele (Hodek lapszerkesztő) őt nem tartja úriembernek, helyette a zavaró külsejü („billegő fejü”) alkalmazott, Mehurek vállalja annak tisztázását. A valóságban nem kerül sor vérontásra, de a föhős álmában folytatódik a történet:

„Ebben azután csakhamar a párbajozandókat látta maga elött, egymás ellen szegezett iromba pisztolyokkal, melyeknek csöve kisebb ágyúcsőnek is beillett. Először Hodek lőtt, szörnyű füstszallag jött ki a fegyveréből, annak köszönhette életét, hogy most is rendes szokása szerint billegette a fejét és éppen félrebillentette a feléje repülő rettenetes nagy golyó útjából. Azután ő lőtt és a golyója épp ádámcsutkán érte Hodeket, aki későn próbálta inggallérját eltekerni és akinek feje most elhajított labda módjára repült el felöle. De sajátságos módon nem esett össze, nem is ejtette el fegyverét, hanem amúgy fej nélkül állva maradt. És Mehurek most neki, Nagybátinak adta át fegyverét, ő maga félreugrott. Nagybáti állt most a porondon szemben már nem Hodekkel, hanem a fejetlen emberrel. És mindkét pisztoly még mindig vagy újra töltve volt, ezt biztosan tudta. A fejetlen végleges biztonsággal célzott - nem dördülés, hanem csattanás hallatszott, de olyan, amitől nem a füldob, hanem az egész emberi agy megszakadhatott. És már repült Nagybáti feje, arca felé a golyó, vagy inkább egy ördögien dühös kifejezésü ólomfej. Rettenetes hasogató fájdalom saját fején keresztül”" (Farkas, 1933: 104). 
A második legfontosabb álomlátása közvetlenül megelőzi a fatelepen kirobbant tűzvészt; az álom valóságba fordulására riad fel: „Ö járt kinn a telepudvarban, ezt biztosan tudta, látta is az iroda-ablakon át. Csodálatos biztonsággal találja meg útját a faölek és gerendasáncok, deszkaépítmények közti mesgyéken, sehol, egyszer sem üti karját vagy lábát bármibe. Pedig nincs feje; széles vállai fölött nyakcsontjából csak egy egészen pislákoló gyertyaláng emelkedik ki” (Farkas, 1933: 127).

A harmadik meghatározó álombeli víziója viszont visszaviszi katonáskodásának színhelyére. Az előbbiekhez képest viszonylag hosszú látomás a gyilkosságot elbeszélő kulcsjelenet előzményeit tárja fel: „Éjszakában volt most is, de meglehetősen hold- vagy csillagfényes éjszakában a szabadban. Valahol Boszniában már közel a Száva folyóhoz, ezt jól tudta. [...] Egyszerre csak egy épület előtt találta magát: fából ácsolt szénapajta, aminő arrafelé szokásos. Körülötte semmi más épület, benne semmi élőlény, bizonyára egy szétszórt fekvésű gazdaságnak legkülsőbb erődje, melyet gazdája csak néhányszor évente keres fel és vesz használatba"9 (Farkas, 1933: 146). A magát ebben az álomban izmos fiatalembernek látó/láttató Nagybáti e pajtában húzza meg magát, $\mathrm{s}$ itt szembesül ismét démonával. Az álom logikai és kronológiai rendjének kuszaságára utal, hogy ezekben a jelenetekben már nála vannak azok a bankók és javak, amelyek a valóságban csak a marhakereskedővel (aki itt már halott) való, e helyszínen történő találkozása után, a gyilkosságot követően kerülnek hozzá:

„Egyszerre mozgást lát. Egy emberi alak két kezével tapogatódzva jár a pajtában, éppenúgy mint az előbb ő maga. Voltaképpen az emberből csak a lábakat látja tisztán, törzse, már a tető árnyékában, sötétben marad. A lábak minduntalan rögöknek, léceknek, cölöpöknek ütődnek, aki itt jön, még annyit sem lát, mint ö maga. Szóljon-e neki, hogy errefelé, nyújtson bajtársi segítő kezet? Nem, nem, inkább sohase érjen ide ez a másik. Pedig közeledik, már a következő pillanatban itt lehet mellette... Már itt is van, megint botlik és lezuhan. Most meglátszik a törzse is, tapogató két keze, de nem a feje, mert az... nincs. A fejetlen alak tehetetlenül lezuhan - egyenesen Nagybáti fejére" (Farkas, 1933: 147).

Nagybáti György kóros lelkiállapotának e szintjén még önmagával szemben határozza meg a Fejnélküli kilétét, akiben az általa tisztázatlan körülmények között megölt marhakereskedő bosszúálló kísértetét (egy halott embert) vélhetjük felfedezni. A tüzvészt követően (amikor a fia életveszélybe kerül) azonban súlyosbodik az állapota. „Emberiesül” a démona.

\section{A démon ,emberiesitése”}

Amíg korábban úgy vélte, a démon ellene tör, az ő fizikai létét veszélyezteti, az események előrehaladtával egyre inkább a fia és a felesége életét kezdi félteni. A fejnélküli ember fiktív világában megnyilatkozó jelenségek megfelelnek a tudós

\footnotetext{
A jelenet tapasztalati alapját Farkas Geiza első világháborús boszniai katonáskodása jelentheti (Ld. Németh, 2004).
} 
Farkas Geiza társadalom-lélektani tanulmánya, a Démonok közt démon-képének, különösen a démon „emberiesítése”-ről szóló kitételnek. Ezek szerint „,az emberre nézve tulajdonképpen minden más ember mindvégig hol felebarát, hol démon" (Farkas, 1923: 12), illetve:

„Itt emlithetjük még némely, olykor különben fejlett értelmiségü embernél is észlelhető különleges, sem kimutatható emlékek sem valamely atavizmus által teljesen meg nem magyarázható előszereteteket, ellenszenveket, félelem- és undorérzeteket, idiosynkrasiákat bizonyos tárgyak vagy személyek iránt kellöleg nem indokolt »imponálásokat « a hysteriának tulajdonított vonzódások és irtózások nagy részét, a megrontó tekintetü emberektől - jellatore - való elterjedt félelmet, végre a páni félelmeket, melyek olykor az embernek nagy tömegeit vonják el hirtelen helyzetük világos áttekintésétől, sodorják végzetes tettekbe, vagy tétlenségekben, ezzel néha még a világtörténelem folyását is eltéritve addigi irányától" (Farkas, 1933:13).

Nagybáti a nyelvi szinten gyakorta megjelenő démoniság, majd az „álom-, láz-, és hallucináció-képek, hangok" (Farkas, 1933: 13) állapotán túl saját tízéves fiában, Karcsiban „emberiesíti” fejnélküli démonát.

Kezdetben a démonnal való fizikai kontaktustól félti a fiát, majd attól tart, hogy az szerettei életére tör, végül (Karcsiék eltévedésének története után) úgy tartja, hogy a démon elragadta tőle gyermekét, s az, aki a fiúban testet öltött, maga a fej nélküli démon-ember:

„És Karcsi? Az egészen a Mária fia, nem az övé. Legalább ő nem ilyen mindig tiszta és rendes, jól tanuló, minden szavát meglatoló, mindenen elgondolkozó, mindenkihez jónak lenni akaró kis tudós, müvész volt tízéves korában. Hanem olyan, aminőnek egy fiúnak lennie kell: rossz és megint rossz, aki bosszantotta, verte a többi gyereket, kifogott a nagyokon, sokszor kerülte az iskolát, kisebbszerü lopásokkal, rablásokkal is megszerezte a csemegét, játékot, melyet éppen áhított, azzal büszkélkedett, hogy minél többféle garázdaságra képes, amiben mások nem tudják utánozni. Karcsinak már az arckifejezése is koraérett, túlkomoly, szinte öreges... Talán csakugyan nem is az ő fia... talán valami titokzatos módon amazé az évekkel Karcsi születése elött... elhalt... másiké...

Talán nem is a fia annak a másiknak, hanem - ö maga. Honnan lenne különben, hogy ő soha egyszerre nem látja a fiát és az ellenséget? Talán az előbbi mindig csak az utóbbinak egy megjelenési alakja volt, melyet azért vett fel, hogy a legteljesebben megadja neki a visszajáró kölcsönkenyeret, s maga számára vegye el mind, ami neki van, amit szerez, legutoljára még a fejét is..." (Farkas, 1933: 211).

Amíg korábban vissza tudott kapcsolni a lázálmok és a hallucinációk, a zavart elmeállapot szintjéről a valóságba, addig ezen a szinten már nincs visszafelé vezető út, a józan logika és a tényeken alapuló magyarázat itt már világértési tapasztalatán kívülre kerül. A befogadó egyes eseményekről többet tud ugyan, mint a föhős (pl. tudjuk, hogy a besurranó tolvaj tettei, akit Nagybáti ugyancsak a Fejnélkülivel azonosít, a jómódúak ellen szövetkező felforgatók tevékenységét jelenti, az eltévedt Karcsi helyzetével visszaélö, de azt végül ki nem használó személy pedig a 
fatelepről elbocsátott Mirko), de a dolgok láncolata (pl. miért épp az elbocsátások után kap lángra a telep?!) egy egészséges lelkületủ és gondolkodású (mint amilyen az ereje teljében levő Nagybáti volt valamikor) ember számára több dolgot is sejtetne, illetve megmagyarázna. Nagybáti azonban végérvényesen elveszíti a küzdelmet. A Fejnélküli képében szubjektívizálódott démon közvetetten, metaforikus értelemben legalábbis, „elvette”, vagyis eltávolította tőle hitvesét, gyermekét, barátait és ismerőseit, hiszen a deviáns magatartás csak egy bizonyos szintig tolerálható; önmaga által generált taszító erővel bír környezetét illetően. Meg is állapítja róla környezete, miszerint ,a város kitünő polgára, Nagybáti György igen megöregedett. Alig múlt negyven éves és már ősz, a járása nehézkes, a tekintete révedező, a beszéde olykor akadozik. Mintha egy félév alatt húsz esztendőt öregedett volna" (Farkas, 1933: 216).

Noha a Nagybátit és a családját ért atrocitásokról (gyújtogatás, névtelen, sértegető levelek, cikkek etc.) sorra kiderül, hogy kisstílü rosszakarók állnak mögöttük, a föhős már képtelen a józan logika szerint élni és gondolkodni - a korábbi önpusztítás módozatai (alkoholizálás, kicsapongó életmód) helyett most ténylegesen is önnön létére tör. Családját tengerparti pihenés ürügyén eltávolítja a környezetéből és éjszakai hallucinációi során többször is megpróbálja elpusztítani a benne lakó szörnyeteget, a démon célpontját. Azért nem a démont magát, mert akkor - a retrográd gondolkodás értelmében - a saját fia életére kellene törnie. Ezzel magyarázhatók halálának furcsa körülményei. Noha orvosi értelemben agy vérzés végzett vele, holttestét úgy találják meg, hogy saját magát fojtogatja.

A regénytörténet konklúziójaként többféle magyarázatot vet fel az elbeszélö - a Nagybáti haláláról beszélgető asztaltársaság tagjainak szájába adva a változatokat -, hogy aztán egyfajta pszichoanalitikai alapú, de a metafizikát sem nélkülöző magyarázat irányába nyisson utat a gondolkodásnak:

„Én sokkal mélyebb értelmét látom Nagybáti képzelgéseinek. Én sem hiszem, hogy ő valaha gyilkossággal jutott volna vagyonához: olyan legénynek, mint ö, nem is volt ilyesmire szüksége. Az a fejetlen ember, akit mikor az élete vége felé járt, untalan maga előtt látott vagy maga körül sejtett, akitől mindig félt, aki ellen örökké harcolt az nem valamely ismert ellensége, még kevésbé a kedves fia volt, - hanem az ő saját nem-én-je..." (Farkas, 1933: 233).

\section{A nyugat-európai legendák}

A fejnélküli ember legendája sokfelé elterjedt a világon: az Egyesült Államokban, Írországban, Skóciában, Németországban, Skandináviában. ${ }^{10}$

Az írek Dullahannak, azaz Fekete embernek nevezik, s nem más, mint egy fejetlen tündér, aki lóháton közlekedik és a fejét a hóna alatt tartja, fegyverként pedig egy emberi holttest gerincéböl készült ostort használ. Ha kiált egy nevet, akkor a megnevezett személy meghal. A skótok fejnélküli lovasa Ewen, egy

$\overline{10}$ Internetes forrás: http://avilagtitkai.blogspot.com/2012/03/fejnelkuli-lovas.html (2015. június 24.) 
lefejezett harcos, aki Mull szigetén kezdett el kísérteni fejnélküli lovas alakjában. Németországban két fejnélküli lovasról szóló történetet ismernek: az egyik Drezda környéki, amely egy nőről szól, aki makkot gyüjtött az erdőben, s ott összetalálkozott egy szürke ló hátán ülő fejnélküli emberrel; a másik Braunschweig térségéből származik, ahol többen látni véltek egy fejnélküli lovast, aki időnként megfújta a kürtjét (amiatt Vadásznak nevezték el). A skandináv történetekben is vadász (Wild Hunt) a fejnélküli lovas, aki mindig fehér lovon lovagol, s egyik változat szerint pedig tököt tart a kezében. ${ }^{11}$ Német nyelvterületen, a fejnélküli ember képzete népmesében is felbukkan (The Wild Huntsmann $)^{12}$. Méghozzá úgy, hogy egy erdőben egy fejnélküli kísértet vesz üldözőbe mindenkit, aki oda betéved. Karl Musäus német származású néprajzkutató is foglalkozott vele ${ }^{13}$. Joggal feltételezhető, hogy az Egyesült Államokban elterjedt (később irodalmi feldolgozásban is megjelent, ma talán a legnépszerübb) fejnélküli lovas-motívumot német nyelvterületről került át oda. Ugyanis, Washington Irving író európai körútja után, 1820-ban írta meg e történetet, (különféle népmesékre és mondákra alapozva) The Sketch Book of Geoffrey Crayon, Gent címü munkájában. Novellájának címe The Legend of Sleepy Hollow (Az Álmosvölgy legendája). Korának legnépszerübb amerikai „fikcionkult”"14 alkotása. Nem véletlen, hogy több film- és tévéváltozat, valamint színpadi és zenei feldolgozás készült róla. A legkorábbi egy némafilm volt 1922-ből, a The Headless Horseman, a legújabb pedig a Sleepy Hollow amerikai tévésorozat 2013-ból.

Joggal feltételezhető, hogy Farkas Geiza gazdag családi könyvtárának kötetei között akadtak a német folklórt, népköltészetet, népmeséket feldolgozó könyvek is, lévén, hogy gyermekkora óta beszélte nemcsak a német, hanem a francia nyelvet is. Szenvedélyes olvasóként ezeket a meséket, legendákat, történeteket már ifjúkorában megismerhette. Feltételezésünk szerint ifjúkori olvasmányaiból származhatott még a fejnélküli ember motívuma.

A fejnélküli ember vizsgálata is arra enged következtetni, hogy Farkas Geiza minden bizonnyal ismerte a fejnélküli lovasról szóló nyugat-európai történeteket, de mindenekelött Washington Irving ${ }^{15}$ (1783-1859) The Legend of Sleepy Hollow (Az Álmosvölgy legendája) címủ novelláját, amelyet a Rip Van Winkle-lel együtt Bartha László 1919-ben magyarra ültetett, és a Népszava kiadásában (Irving, 1919) meg is jelentetett. A fej nélküli lovas legendájából azonban csak a „fejnélküliség”, illetve a saját halála miatti bosszúállás motívumát vette át, illetve a kifejezetten félelemkeltő megjelenés karakterisztikáját. Rokon vonás a fejnélküli

\footnotetext{
Uo.

12 R. V. 2011. A fejnélküli lovas legendája. =Fiction.Kult. fictionkult.hu/cikk/a-fejnelkuli-lovaslegendaja-1087 (2014. 06. 07.)

13 Musäus Folktale (Internetes forrás: http://www.readprint.com/author-50/Washington-Irving). Readprint. com. (2015. június 24.)

14 Utalás az 2003-ban indult, s a tanulmány írása közben adatforrásként használt internetes oldalra. Fiction. Kult. fictionkult.hu/cikk/a-fejnelkuli-lovas-legendaja-1087

15 Washington Irving novellisztikájának legkorábbi fordítása talán a Bajza József [Széplaki Erneszt] által a Pillangó (1836) címú ismert novellaantológia számára lefordított Az özvegy és fia (The Widow and Her Son) volt.
} 
démon megrajzolásában az egyes változatokban (pl. a függetlenségi háborúban elesett német zsoldos katona története) megjelenő katona alakja, aki az utazók létére tör, illetve az a mozzanat, miszerint a démon elött nem léteznek sem térbeli, sem időbeli korlátok (pl. az Irving-novellában a „szelek szárnyán repül” [Irving 1959]). A legenda lényegi összefoglalóját minden elemével maga a novella narrátora adja meg számunkra:

„Egykedvű nyugalmáról, az első hollandus telepesektől leszármazott, különös jellemü lakóiról ezt az elhagyatott szurdokot már régen Álmosvölgy néven ismerik, faragatlan fiait pedig az Álmosvölgy legényeinek hívják az egész országrészben. Mintha valami zsibbasztó, álmos köd ülné meg a tájat, és megmérgezné még a levegőt is. Mesélik, hogy egy felnémet doktor varázsolta el a vidéket még régen, az első telepesek napjaiban; mások azt mondják, hogy itt tartotta tanácskozásait egy indián törzsfönök, aki népe prófétája és varázslója is volt, még mielőtt Hendrick Hudson úr felfedezte volna az országot. Annyi bizonyos, hogy ezt a helyet, valamint a vidék derék lakóinak lelkét varázslat tartja hatalmában, minek következtében az emberek itt úgy jönnek-mennek, mintha folyvást álomban járnának. Mindenféle csodás hiedelemben élnek, révületbe esnek és víziókat látnak, gyakran jelennek meg előttük különös látomások, zenét vagy hangokat hallanak a légből. Az egész környező vidék tele van mindenféle helyi mendemondával, kísértetjárta helyekkel, éji babonával. Több hullócsillag és meteor hasítja át az eget e völgy felett, mint az egész országban együttvéve. Úgy látszik, a lidérc is, mind a kilenc fészekalja gyerekével ezen a helyen járja legjobb kedve szerint vad éji táncait.

Ám a varázslat-megülte táj uralkodó szelleme, s a jelek szerint valamennyi légi hatalom fỏvezére egy lóháton nyargaló kísértet, melynek nincs feje. Egyesek szerint egy hesseni huszár szelleme, kinek a fejét a forradalmi háború valamelyik névtelen csatájában ágyúgolyó tépte le. A vidék népe azóta is meg-megpillantja, amint homályos éji órán a szelek szárnyán lebegve nyargal tova. Nemcsak a völgyet kísérti, hanem időnként a szomszédos vidék útjait is, leginkább pedig egy közeli templom környékét. S valóban, a vidék történetének legszavahihetőbb ismerői, akik a kísértetre vonatkozó kusza tényeket gonddal összegyüjtötték és egybevetették, azt állítják, hogy miután a huszár testét a templomkertben hantolták el, a kísértet éjszakánként innen jár ki a csatamezöre, ahol elvesztett fejét keresi. S néha, amikor úgy nyargal végig a völgyön, mint éji mennydörgés, azért siet, mert késő van, s igyekeznie kell, hogy pirkadat előtt visszaérjen a temetőbe.Ez a rövid summája a legendás babonának, amelyből ezen az árnyaktól népes tájon annyi vad mendemonda született. A kísértetet a családi túzhelyek mellett az Álmosvölgy Fejetlen Huszárjaként emlegetik" (Irving 1959).

Washington Irving története azonban épp annyira rém-, mint amennyire groteszk történet is, hiszen a novella egyik szólama azt sugallja, hogy a fej nélküli lovas legendáját - kihasználva a vidék lakosságának babonás hitét, illetve a térségben idegen, a helyi szokásokat belülről nem ismerő Ichabod Crane tájékozatlanságát - az iskolamester szerelmi vetélytársa, Van Burt (holland 
beceneve: Csontos Brom) használta ki, öltötte magára jelmezét, hogy ezáltal biztosítsa saját győzelmét a szerelmi vetélkedésben - egyébként sikerrel, mert Ichabod Crane csak évtizedekkel később bukkan fel ismét a történetben. A Fejnélküli Lovassal való találkozása sokban hasonlít a Nagybáti elött felbukkanó démon-jelenségével:

„Ichabod, ki ehhez az éjféli útitárshoz vajmi kevés kedvet érzett, s kinek most eszébe jutott Csontos Brom kalandja a Nyargaló Huszárral, meggyorsította lova lépteit, remélve, hogy maga mögött hagyhatja az éji lovast. Ảm az idegen is ugyanolyan gyors ügetésbe kezdett. Ichabod megállt, majd lépésben poroszkált, gondolva, hogy hátramarad - de ugyanígy tett a másik is. Most már hősünk szíve összeszorult; újra megpróbálta zsoltáros énekeit dalolni, de szikkadt nyelve a szájpadlásához tapadt, egyetlen zengzetet nem tudott kiadni. Kitartó útitársának konok, rosszkedvű hallgatásában volt valami titokzatos, valami borzasztó. Hamarosan ki is derült a hallgatás félelmetes oka. Mikor a lovasok egy emelkedőhöz értek, ahol az ég világosabb hátterében Ichabod útitársa köpenybe burkolt, óriás termetének körvonalait kivehette, rémülettel vette észre, hogy az alaknak - nem volt feje! és rémülete még fokozódott, amikor meglátta, hogy a fej, melyet a lovasnak a vállán kellett volna viselnie, ölében, a nyeregkápához támasztva pihent. Ichabod rémülete most már borzadállyá fokozódott, $\mathrm{s}$ ezért ostorcsapások és rúgások özönét záporozta Puskaporra, remélve, hogy gyors iramodással elhagyhatja útitársát - de a kísértet gyors nyargalással mellette maradt. Ekkor bősz vágtába kezdtek mindketten, árkon-bokron át; csak úgy repült a kő és szikrázott a patkó minden ugratásnál. Ichabod vékony öltönyének szárnyai lobogtak a szélben, míg ő maga hosszú, sovány testével elöreborult a ló nyakán, hogy ezzel is könnyítse a menekülést" (Irving 1959).

Ugyanebben a novellában szó esik egy másik rémtörténetről is; egy André nevủ örmester tragikus sorsáról, akit a mocsaras patak bokrai között lesben állva fogtak el a helybeli parasztok, s abból, hogy a közelben álló göcsörtös tulipánfát azóta is André fájának nevezik, arra következtethetünk, hogy erre a fára akasztották fel. A hely azóta is kísértetjárta, s a tragikus sorsú katona alakja összefonódik a Fejnélküli Huszár történetével.

A fejnélküli ember történetéböl teljesen hiányzik a lovas motívuma, ugyanakkor a fejtől megfosztottság, a háború idején gyilkosság áldozatává váló ember, illetve az ôt ért sérelemért elégtételt kereső, azaz mások életét követelő démoniság, a kísértet alakja analóg mozzanat az elbeszélésekben.

A magyar folklórban a felvidéki „permonyik”, azaz a bányaszellem hiedelemmondájában tünt fel és került közzétételre egy gyüjtés során a fej nélküli lovas alakja (L. Juhász, 2002).

\section{Összegzés}

Szenteleky Kornél megfogalmazása szerint, A fejnélküli emberben „a felvetett pszichopatológiai probléma roppant érdekes”, s olyan regény, amelyben „orvos- 
lélektani szempontból nincs semmi kivetnivaló" (Bisztray, Csuka, Szenteleky, 1943: 315.). Értékelése szerint „ilyen nagyszabású patopszichológiai felépítésü regényt nemcsak a Vajdaságban nem írtak, hanem az egész magyar nyelvterületen sem" (Bisztray at al., 1943: 315.).

Csuka Zoltán szerint e regénye „az egykori Becskerek alakjait és korát örökítette meg, s bizony kisebb volt a visszhangja, mint azt megérdemelte volna. Ugyanígy lépett át saját kora egyéb müvein, a kis proligyerekekről írott könyvén, amely a gyermeki lélek mélységes tanulmánya" (Csuka, 1942).

Farkas Geiza $A$ fejnélküli ember címü müvéről elterjedt nézet, hogy „nem kifejezett szépírói vénával megírt alkotás, amelyben a narratív eljárások szövegalkotó szerepe helyett inkább a társadalomtudós lélekbúvár látószöge és esetleírásai (a főhős látomásai, félelmei és álmai) dominálnak" (Bence, 2014: 86). Másrészt az atmoszféra-teremtés és az ok-okozatiság szempontjából rendkívül jól megkomponált, jól működő regény, amelynek egymásra épülő mozzanatai (pl. Nagybáti szellemi leépülése) pszichológiailag is teljesen hitelesek.

Farkas Geiza regénye ugyanakkor az aktuális európai társadalmi történésekre is reflektál (pl. a Nagybátit is érintő „rossz üzletmenet“, amelynek következményeként kénytelen felszámolni kirendeltségeit és munkásainak egy részét elbocsátani), az adott korszakra jellemző gazdasági világválság eseményeit jelöli.

A regény létrejöttének időszakára (a második világháborút megelőző, majd előidéző) militáns újraszerveződés, és az ilyen jellegü hatalmi törekvések előtörése jellemző, amelyeket a háborús tapasztalatokkal rendelkező, a háború jelenségét társadalom-lélektani szempontból vizsgáló és annak eredményeit tanulmányában (Farkas, 1914) közzé is tevő Farkas Geiza azonnal érzékel és - poszttraumás következményeire - reflektál. Az első világháború kitörésekor napvilágot látott munkájában a háborús lelkiállapotot akkut pszichológiai zavarnak tekinti: „,....akik orvosi munkákat is olvasnak, bizonyára észrevették a hasonlatosságot a háborús lelkiállapotról nyújtott vázlatos leírásom és egy heveny elmezavar (acut psychosis) kórtörténete között" (Farkas, 1914).

Jelen kutatásunk ugyanakkor arra is igyekezett rávilágítani, hogy Farkas Geiza A fejnélküli ember címü, 1933-ban megjelent regénye nemcsak a társadalomtudós munkássága és az aktuális társadalomtörténeti események felől olvasható és értelmezhető sikerrel, hanem egy európai kulturális kontextusban is kibonthatók jelentései és intertextuális összefüggései.

\section{FORRÁSOK}

Farkas, G. [1933]. A fejnélküli ember. Szubotica: Kalangya (Kalangya Könyvtár I. kötet. Szerk. Szenteleky Kornél). 


\section{IRODALOM}

Anonim (é. n.). Fej nélküli portrék. http://toochee.postr.hu/fej-nelkuli-portrek (2014. 04. 03.). Bárdosi, V. (2012). Magyar szólások és közmondások adatbázisa. Budapest: Tinta Könyvkiadó. Bisztray, Gy., Csuka, Z. szerk. (1943). Szenteleky Kornél irodalmi levelei 1927-1933. Zombor

Budapest: Szenteleky Társaság.

Bence, E. (2014). A háborús poszttrauma mint elkülönítő létállapot (Farkas Geiza: A fejnélküli ember). Hungarológiai Közlemények, 2, 86-98.

Bori, I. (1971). Farkas Geiza tetszés-esztétikája. Hid, 1, 41-48.

Csetvei, M. (1974). Elfelejtett író elfelejtett regényéről. Farkas Geiza születésének 100. évfordulója. Üzenet, 9, 670-677.

Csuka, Z. (1942). Halk üzenet egy csendes öszi temetésről. Meghalt Farkas Geyza. Torontál, 1942. október 11.

Farkas, G. (1914). A háború lélektana: az idő harcokat újráz. http://sites.google.com/site/ azidoharcokatujraz/home/szarajevo-kavehaz/farkas-geiza-a-haboru-lelektana (2014. 03. 17.)

Farkas, G. (1916). Az emberi csoportok lélektana. http://mtdaportal.extra.hu/.../farkas_geiza_ az_emberi_csoportok_lelektana.pdf'(2014.04.28)

Farkas, G. (1923). Démonok közt. Társadalom-lélektani tanulmány. Budapest: Grill Károly Könyvkiadóvállalata.

Farkas, G. (1925): A társadalmi lélektan köréböl. Három elöadás. Velikibecskerek: Pleitz.

Irving, W. (1919): Rip Van Winkle/Az Álmos-völgy legendája. Ford. Bartha László. Budapest: Népszava.

Irving, W. (1959): Vázlatkönyv. Ford. Lutter László, Végh György. http://mek.oszk. hu/03900/03912/03912.htm (2015. 06. 26.)

Irving, W. (n. d.): The Legend of Sleepy Hollow. Elegant Ebooks. http://www.ibiblio.org/ebooks/ Irving/Sleepy/Irving_Sleepy.pdf (2015. 06. 26.)

Jókia, M. (1974). A löcsei fehér asszony. Regény. Budapest: Szépirodalmi Kiadó.

L. Juhász, I. (2002). A permonyík (A bányaszellem és bányamanó egy gömöri bányásztelepülés, Rudna hiedelemvilágában). Fórum Társadalomtudományi Szemle, 2, http://epa.oszk. hu/00000/00033/00010/ljuhasz.htm (2015. 06. 26)

Németh, F. (2000). „Ez idő volt életemben a legboldogabb”. Farkas Geiza ismeretlen gimnazista önéletrajza 1888-ból. Hid, 1-2., 56-61.

Németh F. (2004). Farkas Geiza imája. Hid, 3, 415-417.

Németh F. (2007). Farkas Geiza kisebb dolgozatai. A két háború közötti vajdasági sajtóban. Hungarológiai Közlemények, 3, 101-119.

Németh F. (2012). „Démonok közt”. Farkas Geiza (1974-1942) társadalomlélektani vizsgálódásairól. In: Egyén és közösség. Szerk. Bárdi Nándor - Tóth Ágnes. Zenta: Vajdasági Magyar Müvelődési Intézet.

R. V. (2011). A fejnélküli lovas legendája. Fiction.Kult. fictionkult.hu/ cikk/a-fejnelkuli-lovas-legendaja-1087 (2014. 06. 07.) 
Erika Bence, Ferenc Nemet

\section{EVROPSKI KULTURNI KONTEKST ROMANA A FEJNÉLKÜLI EMBER (BEZGLAVI ČOVEK) GEJZE FARKAŠA (FARKAS GEIZA)}

Polazna tačka istraživanja o romanu Gejze Farkaša, objavljenom 1933. godine u Subotici, danas uglavnom spominjanog samo u književnoistorijskim napisima, pokreće jedan - po mišljenju istraživača - interkulturalni i intertekstualni motiv koji doseže daleko od regionalne mađarske manjinske književnosti kako u prostornom, tako i u kulturološkom smislu. U romanu se prepoznaju motivi iz različitih narodnih legendi, tj. o irskom Dulahanu (zla vila), o istočnonemačkom lovcu s lovačkim rogom, i o skandinavskom bezglavom jahaču na belom konju - u liku bezglavog demona koji goni glavnog junaka. Međutim, ova priča poznata u zapadnoevropskim kulturama nije iz sveta mitova i legendi prodrla u evropsku književnu i filmsku umetnost, nego iz Amerike. Prema dosadašnjim rezultatima istraživanja, medijska rasprostranjenost ovog motiva poreklo vodi iz jedne zbirke pripovedaka objavljene 1820. godine - zbirke Vašingtona Irvinga pod naslovom The Sketch Book of Geoffrey Crayon, Gent tačnije iz priče strave u sklopu te zbirke The Legend of Sleepy Hollow. Takođe se može pretpostaviti da je Vašington Irving, koji je duže vreme živeo $\mathrm{u}$ Engleskoj, preneo u svoju pripovetku The Legend of Sleepy Hollow jednu legendu zabeleženu od strane nemačkog pisca Karla Muzeusa (Musäus). Takođe, u Americi je poznata priča strave i užasa o jednom bezglavom jahaču koji predstavlja nemačkog vojnika palog u američkom ratu za nezavisnost. Cilj ovog istraživanja je, između ostalog, da se otkrije na koji je način ova zapadnoevropska legenda dospela u književnostvaralački rad ovog pisca s porodičnim poreklom i prostorno vezanim za Budimpeštu, Beč, i banatski Elemir, i postala tematikom.

Ključne reči: Farkas Geiza, bezglavi čovek, zapadnoevropske legende, Vašington Irving, priča strave, posleratna trauma 
Erika Bence, Ferenc Németh

\section{EUROPEAN CULTURAL CONTEXT IN GEIZA FARKAS'S NOVEL $A$ FEJNÉLKÜLI EMBER (THE HEADLESS MAN)}

The starting point of the study on Geiza Farkas's novel A fejnélküli ember, published in 1933 in Subotica, today mostly mentioned only in literary historical texts, initiates - according to researchers - an intercultural and intertextual motif which reaches far beyond the regional Hungarian minority literature, not only in a geographical but also in a cultural sense. The novel features motifs from various legends: the one on Dullahan (the evil fairy), on the Eastern German hunter with a hornet, and on the Scandianavian headless rider on a white horse - in the character of a headless demon pursuing the main protagonist. Nevertheless, this story known in Western European cultures did not come from the world of myths and legends to European literature and cinematography, but from America. According to the obtained findings, the widespread popularity of this motif in the media stems from a collection of short stories published in 1830 - Washington Irving's The Sketch Book of Geoffrey Crayon, Gent more precisely the ghost story in the collection, The Legend of Sleepy Hollow. Apparently, Washington Irving, who lived in England for many years, transferred a legend recorded by the German author Karl Musäus into this latter story. Furthermore, in the USA it is a popular tale of the Headless Horseman who is said to be the ghost of a Hessian trooper who had his head shot off in the American Revolutionary War. The aim of this study, amongst others, is to find out how this Western European legend found its way into the literary work of this writer with a family background and local ties with Budapest, Wienna, and Elemir in Banat.

Key words: Farkas Geiza, headless man, Western European legends, Washington Irving, ghost story, post-World War trauma 